\title{
HSD17B7 wt Allele
}

National Cancer Institute

\section{Source}

National Cancer Institute. HSD17B7 wt Allele. NCI Thesaurus. Code C50885.

Human HSD17B7 wild-type allele is located within $1 \mathrm{q} 23$ and is approximately $22 \mathrm{~kb}$ in length. This allele, which encodes 3-keto-steroid reductase protein, plays a role in the oxidation/reduction of androgens and estrogens. 